\title{
An Evaluation of Agricultural Financing, Policies and Initiatives for Sustainable Development in Nigeria, In the $21^{\text {st }}$ Century: 1990-2014
}

\author{
Dul Solmon Fankun, Grace O. Evbuomwan (Phd) \\ Covenant University Department of Banking and Finance \\ College Of Business and Social Sciences Ota, Ogun State, Nigeria
}

\begin{abstract}
This study is aimed at evaluating agricultural financing, policies, programmes and initiatives for a sustainable development in Nigeria, from 1990-2014, covering a period of 25 years. The dwindling oil prices in the international market necessitate the needs for diversification of the economy, into agriculture for a sustained development in Nigeria. Data for the study were the secondary ones, sourced from the Central Bank of Nigeria (CBN) Statistical Bulletins, Annual Report and Statements of Accounts, Bullion, The Economic and Statistical Review of National Planning Commission, conferences Journals and Publications, World Bank and United Nations publications and text books, using the descriptive and inferential techniques. The findings of the study show that Nigerian Government failed to show enough commitments to agricultural activities for its development towards realization of agricultural sustainable development. This is evident in lack of meeting the minimum 10\% and 25\% budgetary allocation to agriculture as stipulated by Maputo declaration and the Food and Agricultural Organization. It was also found out that commercial bank credits to total credit were too low. There were too many agricultural policies and initiatives that were not matching to actions. Giving the importance of agriculture to any economy, ( provision of food, foreign Earnings, creation of jobs etc) the study recommends the following among others; complying with the minimum $10 \%$ and $25 \%$ minimum agricultural budgetary allocation to agriculture, Government should match words with actions as regards agricultural policies and initiatives, improve investment in agricultural equipment and other inputs to guarantee the achievement of agricultural sustainable development in Nigeria.
\end{abstract}

Keywords: Economy, Agriculture, diversification, sustainability, development.

\section{Introduction}

The main trust of sustainable development in Nigeria is the improvement of good condition of living standard of its citizens. This should be realized by stimulating the economic activities in all critical sectors, especially, the agriculture. Agriculture is the known sector that can bring about enhanced living condition of people for sustainable development (Nnamani, 2009). As the case with Millennium Development Goals (MDGs) from 1990- 2015, (now Sustainable Development Goals) from 2016-2030, underlying all the goals is support to agricultural growth that benefits the poor, for without a renewed effort to fast-track growth in the agricultural sector, few countries will be able to reach the goals, especially the goal of reducing poverty and hunger to $50 \%$ by 2015 . The need to come up with better articulate good practice in agricultural policies, finances, and investment must be handy (www.developmentgoals.org).

According to World Bank Agriculture Investment sourcebook (2005), it states that a growing population and limited natural resources base (agriculture) means that if current and future food and future needs are to be met, these resources will have to be applied in a more sustainable manner. Promoting sustainable agriculture therefore has some requirements such as having good farm management techniques, foster synergized stability, financing and investment in agriculture and to have good agricultural policies and initiatives. Onwioduokit (2013) postulates that prior to the oil boom in Nigeria in the 1960s to 1970s, the economy was largely the agrarian, which employed more than $70 \%$ of the working population of the country. He adds that the oil boom in Nigeria caused the rural-urban drift of the population, to the detriment of agriculture and its output. The study and good revenue from the oil revenue, created the impression that job creation was the sole and primary function of the public sector. Agriculture which has been the main stay of the economy was relegated to the background. However, as the oil fortunes dwindled with the present dispensation, it is now dawn to Nigerians that oil sector can no longer be sustainable, there is now the dearth need to turn to agriculture for a sustainable development of the economy. The agricultural sector has to be financed, and given good policies in order to attain the sustain ability status for development in Nigeria. Financing and good policymaking of this sector will be done through agricultural subsidies, provisions and maintenance of extension and irrigation services to farmers, provision of improved species of animals and seedlings, provisions of mechanized system of farming and the reformation of land tenure system, promote research and development to improve 
agricultural technology, so that there will be improved production of agricultural products, and by implication, leading to the attainment of food security, adequate nutrition, creation of employment as well as raising income of Nigeria citizens (Nnamani, 2009).

\subsection{Statement of the Problem}

Nigeria has been a mono-economy, depending majorly on oil. It has been producing and exporting crude oil for its revenue. The revenue realized from the oil was chunk of money that should be seen as blessing to Nigeria. However, these revenues were mismanaged by colossal corruption, perpetuated in the system in a merciless manner. With the present dispensation, the production level of the oil is reducing, and there is a global dwindling of oil prices, making it difficult for Nigeria to cope with its fiscal budget, both for recurrent, and especially capital expenditure. It is therefore obvious that Nigeria should diversify its economy in order to have a sustainable source of income for a sustained development. It is in the light of the above that the researcher wants to evaluate the level of agricultural financing, policies and initiatives for the attainment of a sustainable development in Nigeria. This is in line with the key role that is played by agricultural sector of all economies, especially the developing ones.

\subsection{Objectives Of The Study}

The following are the objectives of the study;

I. To evaluate the agricultural financing, policies and initiatives to see whether they could lead to sustainable development of the Nigeria economy.

II. To ascertain if there are better agricultural financing, policies and initiatives that could guarantee a sustainable development in Nigeria.

\subsection{Scope Of The Study}

This study covers Nigeria. It is on evaluation of financing, policies and initiatives of agriculture for a sustainable development in Nigeria, from 1990 to 2014, covering a period of 25 years.

\subsection{Significance Of The Study}

The study is aimed at evaluating the financing, policies and initiatives in the agricultural sector in Nigeria, for a sustainable development. The findings from this study will help various stages of Government in Nigeria, thereby helping in policy statement, especially now that the economy is begging for diversification. The Private sectors, Non-Governmental Organizations, farmers and potential farmers will find the findings of the study useful for their decision making process. Researchers and potential ones are likely to benefit from this study.

\subsection{Methodology}

The researcher employs the use of secondary data for the evaluation of the financing, policies and initiatives on agriculture in Nigeria. Data from National Bureau of Statistics, Central Bank of Nigeria Bullions, Annual Reports and Accounts and statistical bulletins of various issues. Journals of related area and text books were also used. The paper uses the descriptive method in analyzing the secondary data collected in order to give policy recommendations.

\subsection{Agriculture}

\section{Conceptual Framework And Review Of Literature}

Suberu et al (2015) in their work, define agriculture as involving the cultivation of land, raising and rearing of animals for providing food for human consumption, raw materials for industrial usage and feed for animals. It composed of crop production, livestock, forestry and fishing. The role of agriculture in the Nigerian economy has remained crucial over the years. Prior to the oil boom, the Nigerian economy was largely agrarian, and it provided for over $70 \%$ of the workforce. Wages rates were as good as what is obtainable in the international standards, indeed, enabling average Nigerian worker to afford good standard of living (Onwioduokit, 2013).

Anyanwu, et al (1997) in their work, state that agricultural development can promote the economic development of an underdeveloped nation in various ways, such as; increasing food supply for domestic consumption, releasing the labour force for industrial employment, enlarging the size of the domestic market for manufacturing sector, increasing the supply of domestic savings and providing earnings from foreign exchange from agricultural exportation. It is important to note that agriculture increases the Gross Domestic Product of a country, thereby growing the economy for the welfare of the citizens. 


\subsection{Agricultural financing}

This refers to the financial services, of provision of short, medium and long term loans, leasing, financial initiatives to agriculture, insurance services, production, distributions, wholesaling, processing and marketing of agricultural produce (www.mfw49.org) Banks and other financial institutions serve as intermediaries between savers and investors, they may supply part or all of the circulating media or means of payment; they may supply initiative and enterprise, as well as finance, for the creation, transformation and expansion of industrial and other ventures, such as agriculture. The fact that the financial system has been inadequate to serve the development needs of the country has been quite obvious, particularly deploring the conservatism of financial system, a situation that remains virtually unchanged over four decades after (Ojo, 2010). The extent to which agriculture which could productively utilize external finance had been unable to obtain such needed finance because of the following reasons or some of them: information gap, lack of available funds, and the inability of the institution to effectively supply funds to the agricultural sector. According to Ojo (2010), the problems of obtaining the right type of finance at the right time, in appropriate or right amount and on satisfactory or right terms, in such a manner that would meet the demand of the deficit economic units for external finance is always there.

\subsubsection{Agricultural financing by financial institutions.}

Finance was identified as a major hindering agricultural production. Commercial banks are seen to be at the forefront for this purpose. One of the major inputs identified over the years in the development of the Nigerian agricultural sector has been the agricultural credit (CBN, 2005). The sources for funding the agricultural sector have been described as the micro and the macro sources of finance. The micro sources relates to the deposits money banks' financing as capital for agricultural activities whereas, agricultural funding through capital mobilization and allocation is by Government through such programmes and initiatives as well as budgetary allocations to the sector. The table below shows bank credit allocation to agricultural sector over the years.

Table 1: Agricultural allocation of bank credit from 1990-2014

\begin{tabular}{|ll|}
\hline 1990 & $16.24 \%$ \\
\hline 1995 & $17.49 \%$ \\
\hline 2000 & $2.46 \%$ \\
\hline 2003 & $5.16 \%$ \\
\hline 2004 & $4.46 \%$ \\
\hline 2005 & $2.44 \%$ \\
\hline 2006 & $1.96 \%$ \\
\hline 2007 & $3.11 \%$ \\
\hline 2008 & $1.37 \%$ \\
\hline 2009 & $1.12 \%$ \\
\hline 2010 & $1.67 \%$ \\
\hline 2011 & $3.50 \%$ \\
\hline 2012 & $3.90 \%$ \\
\hline 2013 & $3.40 \%$ \\
\hline 2014 & $3.90 \%$ \\
\hline
\end{tabular}

Source: CBN ANNUAL REPORTS, 2011 and 2014.

From the above table, you will see how small bank credit for agricultural productivity. The highest percentage of agricultural bank credit to total credits was in 1995, represented by $17.49 \%$. The trend shows sharp reduction, showing percentage of less than 5\% from 2000 to 2014, except for 2003 which shows 5.16\%. This is an evidence of neglect of the agricultural sector in terms of granting credit facilities for some obvious reasons.

\subsubsection{Government allocation/expenditure on Agriculture}

Nigerian Government has not been committing enough funding for the agricultural activities. There have been many agricultural policies, programmes and initiatives, but without much impact to the growth of the sector. The underdeveloped nations like Nigeria make it imperative for government to involve in the agricultural investment necessary. However government spending on agriculture in Nigeria is exceedingly low (Ihugba, et al 2013). The table below shows the extent of Government allocation to agricultural sector. 
Table 2: Government Budgetary allocation to agriculture in Nigeria (1990-2014)

\begin{tabular}{|ll|}
\hline Year & Budgetary allocation $(\%)$ \\
\hline 1990 & $3.2 \%$ \\
\hline 1991 & $1.5 \%$ \\
\hline 1992 & $1.5 \%$ \\
\hline 1993 & $1.7 \%$ \\
\hline 1994 & $2.0 \%$ \\
\hline 1995 & $2.5 \%$ \\
\hline 1996 & $1.8 \%$ \\
\hline 1997 & $2.0 \%$ \\
\hline 1998 & $2.4 \%$ \\
\hline 1999 & $1.5 \%$ \\
\hline 2000 & $1.6 \%$ \\
\hline 2001 & $6.2 \%$ \\
\hline 2002 & $4.0 \%$ \\
\hline 2003 & $1.8 \%$ \\
\hline 2004 & $4.2 \%$ \\
\hline 2005 & $5.5 \%$ \\
\hline 2006 & $1.9 \%$ \\
\hline 2007 & $5.7 \%$ \\
\hline 2008 & $5.9 \%$ \\
\hline 2009 & $5.6 \%$ \\
\hline 2010 & $2.6 \%$ \\
\hline 2011 & $2.4 \%$ \\
\hline 2012 & $1.0 \%$ \\
\hline 2013 & $1.7 \%$ \\
\hline 2014 & $1.4 \%$ \\
\hline
\end{tabular}

Sources: CBN, www.worldbank.org/afr/agperprogram.

From the above table it is obvious that government allocation for agricultural development is low. The highest was in 2001, with $6.2 \%$ of total allocations of government. At the second Ordinary Assembly of the African Union in July 2003 in Maputo, African Heads of Government endorsed the "Maputo Declaration and food security in Africa". The Declaration contained several important decisions regarding agriculture, but prominent among them was the commitment to the allocation of at least $10 \%$ of National Budgetary resources to agriculture, by Comprehensive African Agricultural Development Programme (CAADP-Maputo, 2003). In addition, Food and Agricultural Organization (FAO) recommends that $25 \%$ of Government capital budget be allocated to agricultural development. Both the FAO standard of $25 \%$ and the Maputo declaration of at least $10 \%$ allocation to agriculture failed below achievement by far. From 1990 to 2014 shows an average of $2.8 \%$ as government allocation to agricultural development, which is less than half of the stipulated Africa standard.

\subsubsection{Agriculture contribution to Gross Domestic Product in Nigeria}

Agriculture has not been given its rightful place of priority especially with the discovery of commercial exploration of oil in Nigeria. Be that as it may, it has been contributing significantly to the (economy) Gross Domestic Product of the nation. The representation of the contribution of agriculture to the economy is as shown below.

Table 3: Five-Year average share of agricultural Gross Domestic Product (GDP) contribution in Nigeria from 1990-2014 in percentages

\begin{tabular}{|lc|}
\hline Year & $\%$ contribution \\
\hline $1990-1994$ & $32.55 \%$ \\
\hline $1995-1999$ & $34.32 \%$ \\
\hline $2000-2004$ & $37.05 \%$ \\
\hline $2005-2009$ & $33.50 \%$ \\
\hline $2010-2014$ & $37.02 \%$ \\
\hline
\end{tabular}

Source: National Planning Commission Report (2012), CBN Statistical Bulletin, various issues.

One can see that though low allocation is given to agricultural sector, it has higher comparative contribution to the economy. However more is still expected, when agriculture is given an accelerated attention.

\subsubsection{Government agricultural policies, programmes and initiatives}

The inability of the Government different administration in Nigeria to attain the level of $10 \%$ and $25 \%$ minimum standards of Government allocation to agriculture set by Maputo Declaration and FAO tend to affect the agricultural policies and programmes ( Inanga \& Unemhili, 2011), as cited in (Oyinbo, O, Zakari,A, \& Rekwot, G. Z, 2013). Having realized the declining role of agriculture to economic development, the 
government over the years, has put in place certain policy measures, programmes and initiatives with a view to increasing the contribution of agriculture to the economic development. Ihugba, et al(2013), observed in their work that a peep into the government expenditure on agriculture is portraying a gloomy future for the sector, except a concrete enduring step into the right direction is taken to address the issue of agriculture for sustainable development in Nigeria. Nigerian's agricultural policy objectives since independence in 1960, have geared towards; the achievement of increase in productivity, self-sufficiency in food production, self-sustained growth in agriculture sector and the realization of structural transformation. In pursuance of policy objectives, government has adopted the following policies, projects and initiatives (Eko, et al, 2013).

Table 4: Administration and Agricultural policies, programmes and initiatives in Nigeria from 1990-2014.

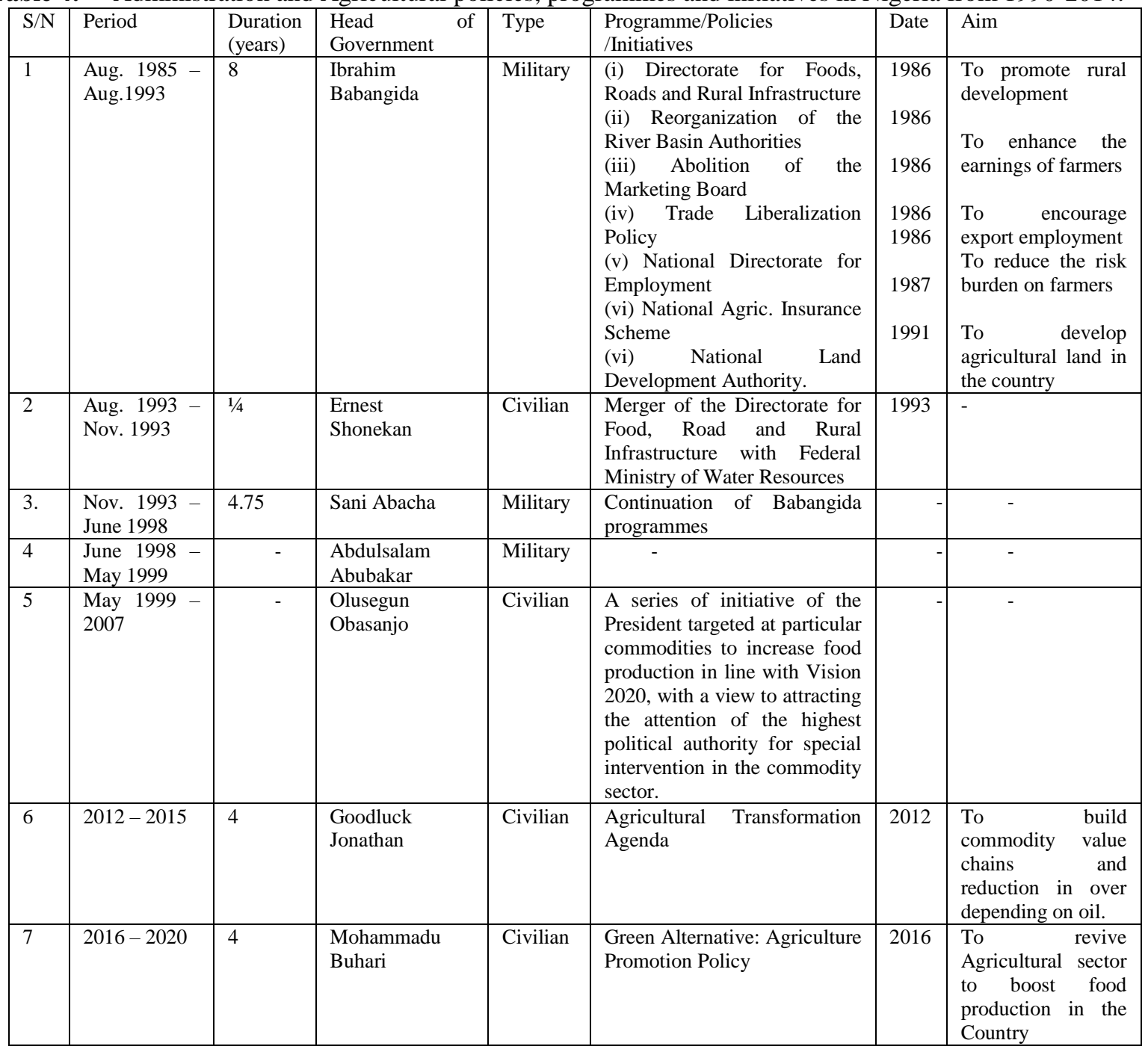

Source: Adopted from Akinboyi, O.L, with modification. CBN Bullion, 2008.

Over the years, the various governments of the country have come up and launched a myriad of agricultural policies, programmes and initiatives in an attempt to stimulate the sustainable growth and development of the agricultural sector. Till date, the achievements of these laudable objectives, remains a subject of debate (Akinboyo, 2008). 1985 to 1993, marked the administration of Ibrahim Babangida. He introduced many agricultural policies. According to Akinboyi (2008), the adoption of Structural Adjustment Programme (SAP) in 1986 was as a result of crises in the Nigerian economy caused by fall in oil in the international market. All other programmes established by him lack strategy for implementation and failed to work. Shonekan lasted for four months with little impact.

The National Land Development Agency (NALDA) established by Abacha was sort of repetition of the Agricultural Development Programmes (ADPs). Programmes initiated by Obasanjo's administration lack funding and therefore without much impact. The seven-point Agenda of Umaru Musa Yar Adua has Food Security and Agriculture as one of it. He brought the vision 2020 20,signifying that the nation can move forward and be among the 20 largest economy by the year 2020. The seven point agenda include; Energy and power, 
food security and agriculture, wealth creation, Education, land Reforms, Mass transit and Niger Delta issue. 2012 to 2015 brought in the administration of Goodluck Jonathan. He brought the Agricultural Transformation Agenda to build commodity value chains and the institutions required to unlock the country's huge agricultural potentials with the targeted outcomes of increasing agricultural for domestic food supply productivity, import substitutions, job creation and reducing over-dependency on oil. Whether ATA has actually attained its objectives, I know your guess is as good as mine.

Green alternative agricultural policy of Muhammadu buhari is to build on whatever the success of the ATA. It is aimed at reviving agricultural sector to boost food production in the country. It will also address the needs for diversification of the economy, especially with the dwindling prices of oil in the international market.

All these policies, programmes and initiatives towards developing agriculture lack government commitment. Good example of this fact is the inability of Nigerian Government to meet up with the minimum stipulated $10 \%$ and $25 \%$ of total Government expenditure to be allocated to agriculture, set by Maputo Declaration and Food and Agricultural organization respectively. No matter how beautiful initiatives could be, if it lacks that commitment, it will be a big blow, thereby hindering the achievement of whatever goals that is intended to be achieved.

\subsection{Sustainable development}

Development refers to the capacity of an economy which had been static for some time, to generate and sustain an annual increase in its Gross National Income (GNI) at rate of 5\% to 7\% or more. Development can also be defined as the rate of growth of income per capita, meaning, the ability to expand the output at a faster rate than the growth of the population of the nation (Linus, 2009). Goulet(1971) describes development as the improvement in the social status of people; it is absolutely participatory process leading to growth and social change. The end product of development is a developed man or woman and their material condition. To sustain, means to keep something or maintain something in existence.

Linus (2009) postulates sustainable development to refer to new approach to economic, social and environmental issues of nation especially the developing ones. The most popular definition of sustainable development has it that it is the development that meets the needs of present, without compromising the ability of the future generation to meet their own needs (Bruntland Commission Report, 1983). It is worth-noting that sustainable development is not restricted to any aspect of development, but comprising the entire ecosystem. That is, in order to attain sustainable development, it has to include a well-thought and plan strategy that include but not restricted to; Human resource management, environmental management, economic sustainability and political development. Anyaehi et al (2015), in their work, posit that the main goal of development is to satisfy human needs and aspiration. It involves actualization of human potentialities, and proper understanding and management of the environment and the resources therein for sustained and continual improvement of quality of human life, both for now and the future.

\section{Challenges To Attainment Of Agricultural Sustainable Development In Nigeria}

Agriculture is generally believed to propel economic growth and facilitate the achievement of structural transformation and diversification of the economy in Nigeria, leading to the attainment of agricultural sustainable development. It empowers a country to fully utilizes its factor endowments and reduce on total or over-dependency on oil for sustainability. Akinboyo(2008) opines that when the agricultural sector is well developed, the economy would gain, as standard living standard of its people will surely improve. With development of agriculture, there will be food security, enhance foreign earnings from agricultural activities, job creation, reduction in over dependency on oil and reduction in importation, especially agricultural imports. As good as this will sound, there are challenges to the attainment of these goals. Some of these are; Lack of commitment to implementation of set down policies, programmes and initiatives for agricultural productivity for the growth of the sector

Technological backwardation for agricultural productivity: Modern agricultural equipment such as tractors, harvester and thresher are lacking. Nigerian farmers are mostly using the crude and outdated methods with less agricultural yield. Nigeria government is not complying with the minimum agricultural budgetary allocation of $10 \%$ and $25 \%$ stipulated by Maputo declaration and FAO respectively. Almost all other challenges are strongly traceable to this because, research and development, training of staff, acquisition of agricultural inputs have to do with financing of the sector. Commercial banks finance to agriculture is quite low as seen in table 1. This may be as a result of the risky nature of agricultural activities and or high interest rates which tend to discourage farmers from borrowing. Economic and political instability: Nigeria as a country is economically and politically instable. AS many as new Government emerged, new economic policies and initiatives equally emerges, without any significant intention order than coining a new name. This practice cannot translate into increasing agricultural productivity in order to guarantee agricultural sustainability in Nigeria. 


\section{Conclusion and Recommendations.}

The role of agriculture, in any economy cannot be compromised, especially in Nigeria, being a developing one. Before the discovery of oil in commercial quantity in Nigeria, in the late $60 \mathrm{~s}$ and $70 \mathrm{~s}$, agriculture has been the main stay of the economy. This was not sustained, as the deception of the oil revenue blinded Nigeria, by neglecting agriculture in favour of the oil. With the current dispensation where there is a sharp reduction in prices in the global market of oil, there is the urgent need to consider agriculture again, by way of diversifying the economy. Having seen the challenges towards realizing these objectives, the following suggestions, based on the findings of this study, are given in order to improve agricultural productivity for a sustainable development in Nigeria.

There should be significant investment in agriculture through human capital development and infrastructural development. This will pave way for increase agricultural productivity. igeria should, as a matter of necessity comply with the minimum $10 \%$ and $25 \%$ budgetary allocation to agriculture as stipulated by Maputo Declaration and FAO respectively. Many other challenges are tied to this as Research and Development, acquisition of modern inputs, training Of personnel etc needs funds. Let there be commitment by the Government of the day to execution of agricultural policies and initiatives. This will amount to matching words with action to see to the growth and development of agriculture for a sustainable development in Nigeria. Government should stimulate the financial system to improve agricultural bank credits. This could be done through Central Bank of Nigeria circular policy about Sectoral Allocation that will be favourable to agricultural sector. In addition, reviewing of interest rates in favour of agricultural sector can equally increase productivity for a sustained agricultural development.

\section{References}

[1] Adabi, A. A (2014). Agriculture: Its problems and prospects; Centre for Local governmentStudies, Ibadan, Nigeria. Jodad Publishers.

[2] Akinboyo, O.L (2008). Five decades of agricultural policies in Nigeria: what roles has statistics played. CBN Bullion vol. 32 N0 4 PP. 35-44

[3] Anyaehi, M. C. \& Areji, A. C. (2015). Economic diversification for sustainable development in Nigeria. Open journal of political science, No.5 pp.87-94.

[4] Anyawu, T. C et al (1997). The structure of the Nigerian economy 1960-1997 Onitsha, Nigeria. Joanee educational publishers

[5] 5. Bruntland Commission Report (1983). Towards sustainable development. Our common future: Report of the World commission on environment and development, UN document

[6] Financing agriculture, www.mfw49.org .Retrieved 10/3/2017

[7] Goulet, D.(1971). The cruel choice. A new concept in the theory of development, New York. Anthenaccum cultural Development.

[8] Ihugba, O. A., Chinedu, N. \& Njoku, A. C. (2013). An assessment of Nigeria expenditure on the agricultural sector: Its relationship with agricultural output 1980-2011. Journal of Economics and International Finance, vol. 5 pp.177-186 August 2013

[9] Maputo (2003). Comprehensive African agriculture development(CAADP)

[10] Nnamani, L. C. (2009). Politics of development and underdevelopment. John Jacobs classic Publishers ltd. Enugu, Nigeria

[11] Obilor, S.I (2013). Impact of commercial banks credit to agriculture on agricultural development in Nigeria: An econometrics analysis. International Journal of business, humanities and technology. Vol. 3, No. 1

[12] Ojo, A. T (2010). The Nigerian maladapted financial system: Reforming tasks and development delimma. CIBN printing press, Lagos, Nigeria.

[13] Onwioduokit, E. A (2013). Unemployment and economic growth in Nigeria, 1980-2013

[14] Central Bank of Nigeria, Bullion, Vol. 36, No. 3 PP. 96-111 \& Vol. 37 No. 1 July 2012-March 2013.

[15] Oyinbo, O., Zakari, A \& Rekwot,G. Z (2013). Agricultural budgetary allocation and economic growth in Nigeria: Implications for agricultural transformation in Nigeria. The Journal of sustainable development. vol. 10, issue 1, pp.16-27.

[16] Suberu, O. J, Ajala, O.A, Akande, M. O \& Olure-Bank, A. (2015). Diversification of the Nigerian economy towards a sustainable growth and economic development. International journal of Economics, finance and Management sciences. Vol. 3, No. 2, pp. 107111.

[17] Sunday, A. E, Clement, A. U, \& Eteng U. O (2013). Beyond oil: Dual imperatives for diversifying the Nigerian economy. Journal of Management and strategy. Vol.4, No. 3 p.83. World Bank Agriculture investment sourcebook 2005.

[18] United Nations Sustainable Development. www.sustainabledevelopment.un.org. Retrieved 12/3/2017

[19] Uzonwanne, M. C (2015). Economic diversification in Nigeria in the face of dwindling oil revenue. Journal of Economics and sustainable development. Vol. 6, No 4 www.africaneconomicoutlook.org. African Economic outlook. Retrieved 10/3/2017. 